\title{
Analisis Mutasi Gen SRY dan AZF serta Fungsi Gonad pada Penderita 46,XY Disorder of Sex Development (DSD)
}

\author{
Meira Erawati ${ }^{1}$, Tri Indah Winarni ${ }^{2}$, Ahmad Zulfa Juniarto $^{2}$, Ardy Santosa $^{3}$, Sultana MH Faradz ${ }^{2}$
}

\begin{abstract}
Objective: Disorder of sex development (DSD) includes congenital conditions in which development of chromosomal, gonadal or anatomy of urogenital is atypical. SRY and AZF genes have relationships with sex development and fertility in 46,XY DSD patients. Therefore, the condition of those genes and gonadal function on 46,XY DSD patients are needed to be explored deeply. The aim of this study was to know the incident number of SRY and AZF genes and gonadal function of 46,XY DSD patients. So that it can be used as one of basic analyses of DSD and infertility status on $46, X Y$ DSD patients .
\end{abstract}

Methods: This is an observational descriptive study with cross sectional approach. This study involved 36 patients that fulfilled the criteria of 46,XY DSD. The DNA of each sample was analyzed by PCR electrophoresis. The data of hCG stimulation test were obtained from secondary data of patient's medical record.

Results: A hundred percent (100\%) of 36 samples did not have deletion on their SRY gene. About 22,22\% of samples had AZFa gene deletion especially on STS sY84. There were 19,44\% samples that showed negative response to hCG stimulation test. Chi square test showed that AZFa deletion did not have relation with gonadal response positifity on 46,XY DSD patients.

Conclusion: Patients of 46,XY DSD need to be evaluated for their fertility especially on the sperm analysis after reaching puberty period. It is done to patients with positive or negative gonadal responses to know whether infertility is influenced by AZF gene or other factors.

Keywords: 46,XY DSD, SRY gene, AZF gene, gonadal function

Gangguan perkembangan seks atau dikenal juga dengan istilah Disorder of Sex Development (DSD) adalah merupakan kondisi kongenital dimana terjadi ketidakjelasan perkembangan seks yang dinilai dari keadaan kromosom, gonad, maupun anatomi saluran urogenital. ${ }^{1}$ Gen SRY yang terletak pada lengan pendek kromosom Y (Yp1.1) menyebabkan produksi faktor transkripsi SRY yang dengan bantuan gen-gen lain di luar kromosom Y, memacu gonad berdiferensiasi menjadi testis. ${ }^{2}$ Ditemukannya mutasi gen SRY pada kasus Gonadal Dysgenesis

1. Program Studi Ilmu Keperawatan Fakultas Kedokteran Universitas Diponegoro Semarang

2. Pusat Riset Ilmu Biomedik Fakultas Kedokteran Universitas Diponegoro Semarang

3. Bagian Urologi/SMF Bedah Fakultas Kedokteran Universitas Diponegoro - RSUP Dr Kariadi Semarang
Syndrome dan hermaphroditisme memperlihatkan peran gen SRY pada terjadinya kasus DSD khususnya individu dengan kromosom $46, \mathrm{XY} .^{3}$

Lokus gen AZF merupakan lokus yang berisi gen-gen yang bertanggung jawab terhadap proses spermatogenesis pada manusia. Lokus gen AZF terdapat pada kromosom $Y$ tepatnya pada lengan panjang regio 1 band 1 (Yq1.1). Regio AZF ini terbagi dalam tiga bagian yaitu yang disebut sebagai AZFa, AZFb dan AZFc. ${ }^{4}$ Delesi gen pada lokus AZF khususnya AZFa, memiliki peran yang nyata pada proses patologi testicular yang berat disertai dengan tidak terbentuknya sel-sel germinal. ${ }^{5}$

Status fertilitas pada penderita DSD yang memiliki kromosom Y bervariasi dari fertil sampai dengan infertil. Variasi status fertilitas pada penderita DSD ini besar kemungkinan dipengaruhi 
oleh peran gen AZF. Tes stimulasi hCG dilakukan untuk menguji fungsi gonad pada laki-laki yang mempunyai gen SRY. Indikasi tes stimulasi hCG antara lain dilakukan pada bayi dengan ambiguitas genitalia dan testis yang teraba, pada laki-laki dengan keterlambatan puber dan atau testis yang tidak turun, yang mana kelainan-kelainan tersebut termasuk di dalam kategori 46,XY DSD. ${ }^{6}$

Berdasarkan penjelasan di atas, penelitian ini bertujuan untuk mengetahui angka kejadian mutasi gen SRY dan gen AZF serta fungsi gonad pada penderita 46,XY Disorder of Sex Development (DSD) dengan harapan hasil penelitian ini dapat memberikan dasar informasi ilmiah mengenai angka kejadian mutasi gen SRY dan gen AZF serta fungsi gonad pada penderita 46,XY DSD

\section{METODE}

Penelitian ini adalah penelitian observasional deskriptif dengan melibatkan 36 sampel penderita baru yang tercatat di Laboratorium Pusat Riset Biomedik (Center for Biomedical Research : Cebior) Fakultas Kedokteran Universitas Diponegoro pada tahun 2008. Data hasil pemeriksaan kromosom dan pemeriksaan fungsi gonad dengan stimulasi hCG merupakan data sekunder yang diambil berdasarkan catatan medis penderita. Interpretasi pemeriksaan fungsi gonad dinyatakan dengan respon gonad positif (+) dan respon gonad negatif (-). Sampel yang diikutkan dalam penelitian adalah sampel dengan hasil katiotip 46,XY. DNA sampel didapatkan melalui proses ekstraksi DNA dengan metode salting out. Analisis gen SRY dan AZF dilakukan dengan metode PCR. Sekuen dari primer PCR gen SRY dan AZF seperti terlihat pada tabel 1.

Tabel 1 . Sekuen dari primer PCR untuk gen SRY dan AZF

\begin{tabular}{|c|c|c|c|c|}
\hline $\begin{array}{c}\text { Primer } \\
\text { Multiplex }\end{array}$ & $\begin{array}{c}\text { Region } \\
\text { gen }\end{array}$ & $\begin{array}{c}\text { Kode } \\
\text { Sekuen }\end{array}$ & $\begin{array}{c}\text { Besar } \\
\text { Produk } \\
\end{array}$ & Sekuen \\
\hline$A$ & $\mathrm{AZFa}$ & sY86 & $320 \mathrm{bp}$ & $\begin{array}{l}\mathrm{F}: \text { gtgacacacagactatgcttc } \\
\mathrm{R}: \text { acacacagagggacaacc }\end{array}$ \\
\hline B & & sY84 & $326 \mathrm{bp}$ & $\begin{array}{l}\mathrm{F} \text { : agaagggtctgaaagcaggt } \\
\mathrm{R} \text { : gcctactacctggaggcttc }\end{array}$ \\
\hline A & $\mathrm{AZFb}$ & sY127 & $274 \mathrm{bp}$ & $\begin{array}{l}\text { F : ggctcacaaacgaaaagaaa } \\
\text { R : ctgcagg cagtaataaggga }\end{array}$ \\
\hline B & & sY134 & $301 b p$ & $\begin{array}{l}\mathrm{F}: \text { gtctgcctcaccataaaacg } \\
\mathrm{R}: \text { accactgccaaaactttcaa }\end{array}$ \\
\hline A & $\mathrm{AZFC}$ & sY254 & $400 \mathrm{bp}$ & $\begin{array}{l}\text { F : gggtgttaccagaaggcaaa } \\
\text { R:gaaccgtatctaccaaagcagc }\end{array}$ \\
\hline B & & s 255 & $126 \mathrm{bp}$ & $\begin{array}{l}\mathrm{F} \text { : gttacaggattcggcgtgat } \\
\mathrm{R}: \text { ctcgtcatgtgcagccac }\end{array}$ \\
\hline$A$ dan $B$ & $\mathrm{ZFY}$ & & $495 \mathrm{bp}$ & $\begin{array}{l}\text { F: accrctgtactgactgtgattaca } \\
\text { R: gcacytcttggtatcygagaaagt }\end{array}$ \\
\hline A dan B & SRY & & $472 \mathrm{bp}$ & $\begin{array}{l}\mathrm{F}: \text { gaatattcccgctctccgga } \\
\mathrm{R}: \text { gctggtgctccattcttgag }\end{array}$ \\
\hline
\end{tabular}

Sumber: Simoni et al, $2004^{7}$

Proses amplifikasi dengan PCR (sebagaimana mengikuti Hybrid Touch Down Thermocycler, Dynex Hybald Lab System, Frankfurt, Germany) dimulai dengan langkah denaturasi inisial selama 15 menit pada suhu $95^{\circ} \mathrm{C}$, diikuti oleh 35 siklus yang terdiri dari 30 detik denaturasi $\left(94^{\circ} \mathrm{C}\right)$, annealing 90 detik $\left(57^{\circ} \mathrm{C}\right)$ dan elongasi 60 detik $\left(72^{\circ} \mathrm{C}\right)$, diakhiri dengan langkah pemanjangan akhir 10 menit dan pendinginan $4^{\circ} \mathrm{C} .{ }^{8}$ Langkah selanjutnya setelah PCR adalah elektroforesis. Produk PCR dielektroforesis dalam gel agarose $4 \%$ dan dijalankan pada tegangan $100 \mathrm{~V}$ selama \pm 2 jam. DNA hasil elektroforesis diamati menggunakan iluminator ultraviolet untuk melihat ada dan tidaknya delesi pada gen SRY serta region gen AZF. Kolom blangko digunakan untuk mengetahui ada tidaknya kontaminasi. Kolom kontrol laki-laki dan perempuan normal digunakan sebagai pembanding dan mengetahui keberhasilan 
proses elektroforesis. Kontrol internal dalam penelitian ini adalah gen ZFY. Variasi fungsi gonad pada sampel yang mengalami delesi gen dianalisis lebih lanjut dengan menggunakan analisis statistik Chi Square.

\section{HASIL}

Sejumlah 36 sampel telah dilakukan analisis molekuler dengan metode PCR dengan sebelumnya telah dipastikan keberadaan kontrol internal (ZFY : 495 bp). Hasil PCR dengan menggunakan multipleks A pada semua sampel menunjukkan tidak adanya delesi, baik pada region SRY, AZFa (sY86), $\mathrm{AZFb}$ (sY127) maupun AZFc (sY254). Hal ini ditunjukkan dengan munculnya semua pita pada region SRY (472 bp), AZFa (320 bp), AZFb (274 bp) serta AZFc (400 bp).

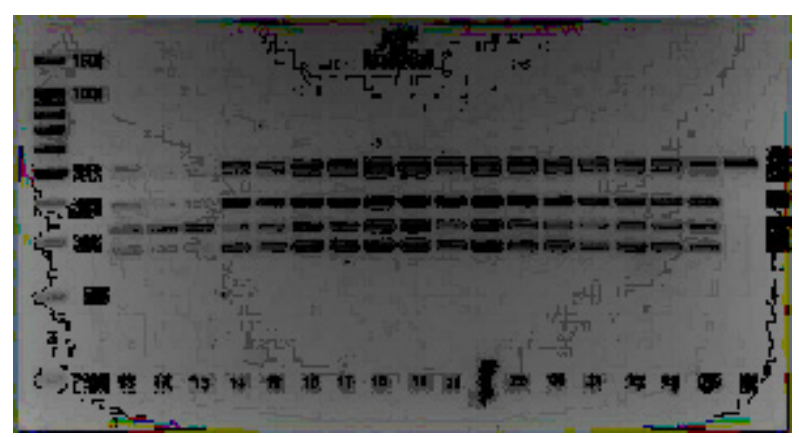

Gambar 1. Gambaran produk hasil PCR elektroforesis gen SRY dan AZF dengan primer Multipleks A. Kolom Marker ladder 100 bp, angka 11 s.d. 26 : nomer sampel 11 s.d 26, kolom CM: (Control Male) kontrol lakilaki, kolom CF: (Control Female) kontrol perempuan, kolom besar produk: besarnya produk PCR. Angka 495 : besarnya produk gen ZFY (kontrol internal) 495 bp, 472 : besarnya produk gen SRY 472 bp, 400 : besarnya produk AZFc 400 bp, 320 : besarnya produk AZFa 320 bp, 274 : besarnya produk AZFb 274 bp.
Data hasil analisis molekuler dengan menggunakan multipleks B menunjukkan sejumlah 8 sampel mengalami delesi, antara lain pada sampel nomer 8, 11, 14, 16, 17, 19, 21 dan 33. Delesi yang ditunjukkan pada kedelapan sampel tersebut semuanya terjadi pada region AZFa, ditandai dengan hilangnya pita pada besar produk $326 \mathrm{bp}$ dengan kode sekuen sY84. Gambaran delesi ini dapat dilihat pada gambar 2, sedangkan data keseluruhan hasil analisis molekuler gen SRY dan AZF dapat dilihat pada tabel 2 .

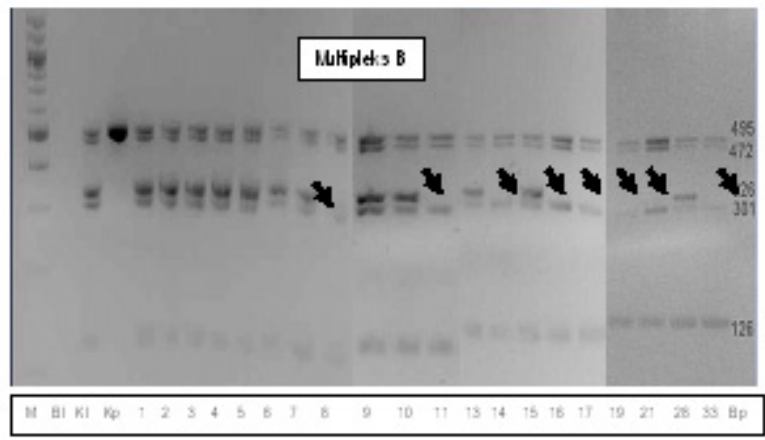

Gambar 2. Gambaran produk hasil PCR elektroforesis gen SRY dan AZF dengan primer Multipleks B. Kolom M : Marker ladder 100 bp, kolom Bl : Blanko, kolom Kl : Kontrol laki-laki, kolom Kp : Kontrol perempuan, Angka 1 s.d. 33 : nomer sampel 1 s.d 33, kolom Bp : Besarnya produk PCR. Angka 495 : besarnya produk gen ZFY (kontrol internal) 495 bp, 472 : besarnya produk gen SRY 472 bp, 326 : besarnya produk AZFa 326 bp, 301 : besarnya produk AZFb 301 bp, 126 : besarnya produk AZFc 126 bp. Tanda anak panah menunjukkan gambaran terjadinya delesi gen AZFa pada sampel nomer 8, 11, 14, 16, 17, 19, 21 dan 33 ditandai dengan hilangnya pita pada besar produk 326 bp pada sampel-sampel tersebut.

Tabel 2. Data hasil analisis molekuler dengan PCR elektroforesis gen SRY dan AZF pada penderita 46,XY DSD

\begin{tabular}{cccccccc}
\hline & SRY & \multicolumn{2}{c}{ AZFa } & \multicolumn{2}{c}{ AZFb } & \multicolumn{2}{c}{ AZFc } \\
& & sY86 & sY84 & sY 127 & sY 134 & sY254 & sY 255 \\
Normal & 36 & 36 & 28 & 36 & 36 & 36 & 36 \\
$\%$ & 100 & 100 & 77,78 & 100 & 100 & 100 & 100 \\
Delesi & 0 & 0 & 8 & 0 & 0 & 0 & 0 \\
$\%$ & 0 & 0 & 22,22 & 0 & 0 & 0 & 0 \\
Total & 36 & 36 & 36 & 36 & 36 & 36 & 36 \\
$\%$ & 100 & 100 & 100 & 100 & 100 & 100 & 100 \\
\hline
\end{tabular}


Hasil analisis fungsi sel leydig gonad yang dilihat dari nilai hormon testosteron setelah dilakukannya tes stimulasi hCG ditunjukkan pada gambar 2.

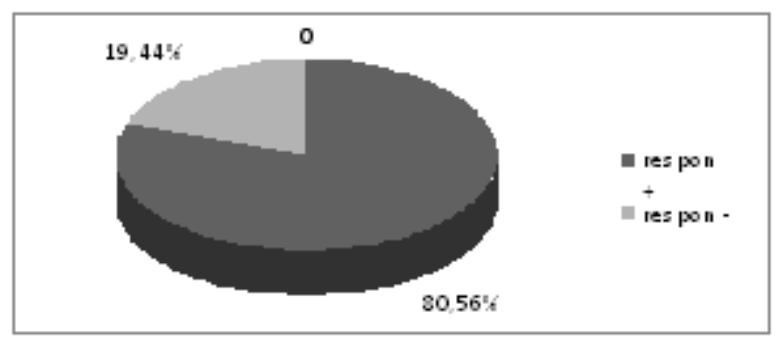

Gambar 2. Distribusi frekuensi responden berdasarkan respon sel leydig gonad terhadap tes stimulasi hCG yang dilihat dari nilai testosteron pada penderita 46,XY DSD
Keterangan :

(respon + ) : menunjukkan adanya respon sel leydig gonad terhadap tes stimulasi hCG. Hasil ini menggambarkan bahwa sel leydig gonad dapat berfungsi memproduksi hormone testosterone, ditandai dengan terjadinya peningkatan nilai testosterone dari sebelum stimulasi dan setelah stimulasi hCG

(respon -) : menunjukkan tidak adanya respon sel leydig gonad terhadap tes stimulasi hCG. Hasil ini menggambarkan bahwa sel leydig gonad tidak dapat berfungsi memproduksi hormone testosterone, ditandai dengan tidak adanya peningkatan nilai testosterone dari sebelum stimulasi dan setelah stimulasi hCG

Tabel 3. Tabel kontingensi respon gonad penderita 46,XY DSD terhadap stimulasi hCG pada AZFa delesi maupun AZFa tanpa delesi

\begin{tabular}{lcccc}
\hline & \multicolumn{2}{c}{$\begin{array}{c}\text { Respon gonad terhadap } \\
\text { stimulasi hCG }\end{array}$} & Jumlah & P \\
\cline { 2 - 3 } & Positif & Negatif & & \\
AZFa tanpa delesi & $23(63,9 \%)$ & $5(13,9 \%)$ & & $28(77,8 \%)$ \\
AZFa delesi & $6(16,7 \%)$ & $2(5,6 \%)$ & $8(22,2 \%)$ & \\
Jumlah & $29(80,6 \%)$ & $7(19,4 \%)$ & $36(100 \%)$ & 0,497
\end{tabular}

Hasil uji Chi square menunjukkan hasil walaupun respon gonad terhadap stimulasi hCG dengan hasil positif pada AZFa tanpa delesi lebih besar daripada AZFa dengan delesi, tetapi distribusi keduanya tidak berbeda bermakna $(\mathrm{p}=0,497)$. Dengan demikian maka tidak ada hubungan antara AZFa delesi dengan positifitas respon gonad.

\section{PEMBAHASAN}

Penelitian ini menunjukkan tidak satupun sampel yang mengalami delesi pada gen SRY, namun seluruhnya masuk dalam kategori penderita 46,XY DSD. Keadaan ini menjelaskan bahwa gen SRY dalam keadaan tidak mengalami delesi, tetapi kondisi yang dialami oleh penderita berhubungan dengan faktor penyebab 46,XY DSD lain di luar gen SRY. Hasil penelitian ini serupa dengan penelitian sebelumnya yang mendapatkan koding sekuens gen SRY yang normal pada perempuan dengan 46,XY Complete Gonadal Dysgenesis. ${ }^{9}$ Pada penelitian yang lain juga didapatkan hanya sekitar
$15 \%$ penderita 46,XY Gonadal Dysgenesis menunjukkan terjadinya mutasi gen SRY, sementara $85 \%$ yang lainnya memiliki gen SRY dalam keadaan normal. ${ }^{10}$

Berdasarkan data hasil penelitian di atas, maka dapat dijelaskan bahwa diferensiasi seksual merupakan proses yang melibatkan banyak faktor, dan gen SRY hanya merupakan salah satu faktor yang terlibat di dalamnya, meskipun gen SRY merupakan salah satu faktor kunci yang sangat menentukan proses diferensiasi seks tersebut. Namun demikian gen SRY bukan merupakan satusatunya faktor penentu perkembangan seks, sehingga apabila terjadi penyimpangan proses diferensiasi seks maka salah satu kemungkinan bisa saja disebabkan oleh terjadinya mutasi pada gen SRY atau bisa juga disebabkan oleh faktor lain yang juga mempunyai peran dalam proses perkembangan seks. ${ }^{11}$

Sejumlah 36 kasus 46,XY DSD yang terlibat di dalam penelitian ini, kejadian delesi pada region 
AZFa adalah sebanyak 22,22\% (8 dari 36) sampel, dan seluruhnya terjadi pada Sequence tagged sites (STS) sY84. Sementara pada kedua region yang lain yaitu AZFb dan AZFc tidak satupun ditemukan terjadinya delesi. Hasil serupa ditunjukkan oleh penelitian sebelumnya dimana didapatkan delesi pada regio AZFa khususnya STS sY84 yang dilakukan pada laki-laki dengan infertilitas. ${ }^{12} \mathrm{Hal}$ ini juga sesuai dengan penelitian yang dilakukan pada kasus azoospermia dan oligozoospermia berat dimana terjadi mikrodelesi pada ketiga region gen AZF. Pada kasus azoospermia frekuensi delesi AZFa mencapai 43,4\%., delesi AZFb mencapai 8,6\% dan delesi AZFc mencapai $17,4 \%$. Sementara itu pada kasus oligozoospermia berat frekuensi delesi AZFa mencapai $40 \%$, delesi AZFb mencapai 5\% dan delesi AZFc mencapai 5\%. ${ }^{13}$ Penjelasan tersebut menggambarkan frekuensi terjadinya delesi pada region $A Z F a$ lebih besar dibandingkan dengan kedua regio gen $A Z F$ yang lain yaitu $A Z F b$ dan $A Z F c$.

Delesi pada gen AZF, khususnya regio AZFa berkaitan dengan ketidakberadaan sel-sel germinal secara komplit pada testis. Keadaan ini merupakan karakteristik dari Sertoli Cell Only Syndrome $(S C O S) .{ }^{14}$ Selain ditemukan pada penderita SCOS, delesi regio AZFa juga ditemukan pada penderita yang memiliki struktur testis immature, ${ }^{15}$ dimana hubungan antara terjadinya delesi regio AZFa terisolasi dengan histologi testis merupakan suatu rentang yang bervariasi dari SCOS sampai hipospermatogenesis yang berat. ${ }^{16}$

Pendapat tentang hubungan antara delesi regio AZFa dengan kelainan histologi testis seperti yang telah disampaikan di atas, diperkuat dengan hasil penelitian yang mendapatkan bahwa delesi gen DBY yang terdapat pada regio AZFa merupakan kejadian tersering dari patologi testis pada laki-laki yang mengalami delesi pada regio AZFa. Hal ini didukung oleh penelitian yang mendapatkan bahwa hasil transkripsi dari gen DBY ini dapat ditemukan pada berbagai jaringan yang diperiksa meskipun secara dominan ditemukan pada jaringan testis, namun demikian hasil translasi dari gen DBY ini hanya terdeteksi pada sel-sel germinal saja. ${ }^{17}$ Selain gen DBY pada regio AZFa juga terdapat gen USP9Y. Gen USP9Y ini juga merupakan gen fungsional yang terekspresi secara luas. ${ }^{18}$ Meskipun fungsi dari gen USP9Y ini belum diketahui secara pasti, namun pada sebuah penelitian terdahulu ditemukan terjadinya delesi gen USP9Y pada kasus SCOS. Frekuensi delesi gen USP9Y ini cukup tinggi yaitu sebesar $18,2 \% .^{19}$

Pendapat di atas menjelaskan apabila terjadi delesi pada regio gen AZFa yang di dalamnya juga terjadi delesi gen DBY atau gen USP9Y atau bahkan keduanya dimana ini menyebabkan keadaan patologi pada testis, maka secara tidak langsung delesi ini dapat menjadi penyebab kelainan pada sel leydig yang juga terdapat pada testis. Sementara itu telah diketahui bahwa sel leydig merupakan sel yang memproduksi testosteron, dimana testosteron ini dibutuhkan dalam proses perkembangan seks khususnya organ genetalia eksterna dengan sebelumnya dikonversi terlebih dahulu menjadi dihidrotestosteron oleh 5 á reductase. ${ }^{20}$ Sehingga apabila terjadi delesi pada gen DBY atau gen USP9Y atau keduanya yang terdapat pada regio AZFa ini maka pada akhirnya dapat berakibat terganggunya perkembangan organ genitalia eksterna yang merupakan salah satu gambaran dari DSD.

Dilakukannya pengamatan terhadap hasil tes stimulasi hCG pada penelitian kali ini bertujuan untuk mengetahui gambaran fungsi gonad khususnya sel leydig pada penderita 46,XY DSD. Berdasarkan data tes stimulasi hCG dari rekam medis penderita yang berhasil dikumpulkan, maka dari 36 sampel yang terlibat dalam penelitian ini, $19,44 \%$ (7 dari 36) sampel memperlihatkan sel leydig gonad tidak berfungsi dengan baik yang ditandai dengan tidak adanya respon peningkatan nilai hormon testosteron dari sebelum dan setelah tes stimulasi hCG, sementara 80,56\% (29 dari 36) sampel lainnya memperlihatkan fungsi sel leydig gonad yang baik dimana terjadi respon peningkatan nilai hormon testosteron setelah tes stimulasi hCG, dengan nilai peningkatan minimal mencapai dua kali dari nilai testosteron awal sebelum pemberian hormon hCG. Hal ini disebabkan oleh karena penyebab dari gangguan perkembangan seks pada individu 46,XY yang satu dengan yang lain berbedabeda sehingga berakibat kepada respon yang menggambarkan fungsi gonad yang juga berbedabeda. Hasil ini sesuai dengan penelitian terdahulu yang mendapatkan juga variasi respon gonad pada penderita gangguan perkembangan seks yang dikelompokkan berdasarkan kelainan yang didapatkan. ${ }^{21}$

Hasil respon gonad positif menggambarkan 
bahwa sel leydig gonad dapat berfungsi memproduksi hormon testosteron yang dibutuhkan dalam proses diferensiasi seks pada awal perkembangan janin, maupun pada proses pematangan sperma yang dikenal dengan istilah spermatogenesis. Di dalam penelitian ini $80,56 \%$ sampel 46,XY DSD memperlihatkan respon gonad positif terhadap stimulasi hCG, maka ini berarti bahwa sebagian besar penderita 46,XY DSD memiliki fungsi gonad yang baik. Dengan fungsi gonad yang baik dalam menghasilkan testosteron memungkinkan proses spermatogenesis dapat berjalan dengan baik. Sementara itu 19,44\% responden memperlihatkan respon gonad negatif yang menggambarkan bahwa sel leydig gonad pada sebagian kecil penderita 46,XY DSD tidak dapat memproduksi hormon testosteron dengan baik sehingga akan mengganggu proses spermatogenesis yang pada akhirnya akan berdampak pada penurunan fertilitas pada laki-laki. ${ }^{22}$

Hasil uji Chi square memperlihatkan hasil walaupun respon gonad terhadap stimulasi hCG dengan hasil positif pada AZFa tanpa delesi lebih besar daripada AZFa dengan delesi, tetapi distribusi keduanya tidak berbeda bermakna. Dengan demikian maka tidak ada hubungan antara AZFa delesi dengan positifitas respon gonad. Hal ini sesuai dengan penelitian terdahulu dimana didapatkan delesi gen AZFa pada kasus SCOS,${ }^{14}$ yang disertai dengan terganggunya proses aktivitas sekresi sel leydig dalam memproduksi hormon testosteron. ${ }^{23}$ Pada penelitian lain terjadinya delesi gen AZFa pada kasus SCOS tidak disertai dengan gangguan fungsi sel leydig ditandai dengan produksi hormon testosteron dengan jumlah yang normal. ${ }^{24}$ Kedua hasil penelitian di atas menunjukkan bahwa delesi AZFa tidak berpengaruh pada fungsi gonad khususnya fungsi sekresi hormon testosteron.

\section{KESIMPULAN}

Kesimpulan yang didapatkan dari penelitian ini adalah ditemukannya delesi pada AZFa sejumlah $22,22 \%$ serta tidak ditemukan delesi gen SRY, AZFb maupun AZFc pada kasus 46,XY DSD. Sebanyak $19,44 \%$ sampel memperlihatkan respon gonad negatif. Berdasarkan respon gonad penderita dengan dan tanpa delesi gen AZFa menunjukkan bahwa tidak ada hubungan delesi gen AZFa dengan positifitas respon gonad penderita 46,XY DSD.

\section{DAFTAR RUJUKAN}

1. Consortium on the management of disorders of sex development. Clinical guidelines for the management of disorders of sex development in childhood. [document on the internet]. North America : Intersex society of North America; 2006 [updated 2006 August 16; cited 2009 February 15]. Available from : http:// www.dsdguidlines.org.

2. Wilhelm D, Palmer S, Koopman P. Sex determination and gonadal development in mammals. Physiol Rev 2007; 87:1-28

3. Braun A, Kammerer S, Cleve H, Lohrs U, Schwartz HP, Kuhnle U. True hermaphroditism in $46, X Y$ individual caused by postzygotic somatic point mutation in the male gonadal sex determining locus (SRY): molecular genetic and histologic findings in a sporadic case. Am J Hum Genet 1993; 52:578-85

4. Martinez MC, Bernabe MJ, Gomez E, Ballesteras A, Landeras J. Screening for AZF deletion in a large series of severely impaired spermatogenesis patients. J Androl 2000; 21(5) : 651-5

5. Vogt PH. Genomic heterogeneity and stability of the AZF locus on the human Y chromosome. Mol and Cell Endoc 2004; 224:1-9

6. Loy CJ, Yong EL. Sex, infertility and the molecular biology of the androgen receptor. Curr Opin Obstret Gynecol 2001; 13:315-21

7. Simoni M, Bakker E, Krausz C. EAA/EMQN best practice guidelines for molecular diagnosis of y-chromosomal microdeletions : State of the art. Int J Androl 2004; 27:240-9

8. Mutair A, Iqbal MA, Sakati N, Ashwal A. Cytogenetics and etiology of ambiguous genetalia in 120 pediatric patients. Ann Saudi Med 2004; 24:368-72

9. Dumic M, Lin-Su K, Leibel NI, Ciglar S, Vinci G, Lasan R, et al. Report of fertility in a woman with a predominantly $46, X Y$ karyotype in a family with multiple disorders of sexual development. J Clin End \& Metab 2007; 0 : 2007-155 
10.Cameron R, Sinclair AH. Mutation in SRY and SOX9 : testis determining genes. Hum Mutat 1997; 9: 388-95

11. Canto P, Galicia N, Soderlund D, Escudero I, Mendez JP. Screening for mutations in the SRY gene in patients with gonadal dysgenesis or with turner syndrome and Y mosaicism. Eur J Obstet Gynecol Reprod Biol 2004; 115 (1) : 55-8

12.Rodovalho RG, Arruda JT, Moura KKVO. Tracking microdeletions of the AZF region in patrilineal line of infertile men. Genet Mol Res. 2008; 7(3) : 614-22

13.Arruda JT, Bordin BM, Santos PR, Masquita WEJC, Silva RCPC, Maia MCS, et al. Y chromosome microdeletions in Brazilian fertility clinic patients. Genet. Mol. Res 2007; 6(2) : 4619

14.Lin YM, Teng YN, Lee PC, Lin YH, Hsu CC, Lin CS, et al. AZFa candidate gene deletions in Taiwanese patients with spermatogenic failure, J Formos Med Assoc 2001; 100:592-7

15.El-Awady MK, El-Shater SF, Ragaa E, Atef K, Shahee IM, Megiud NA. Molecular study on Ychromosome microdeletions in Egyption males with idiophatic infertility. Asian J Androl 2004; $6: 53-7$

16. Yen PH, Li XM, Tsai SP, Johnson C, Mohandas T, Shapiro LJ. Frequent deletions of the human $\mathrm{X}$ chromosome distal short arm result from recombination between low copy repetitive elements. Cell 1990; 61 : 603-10
17.Ditton HJ, Zimmer J, Kamp C, De-Meyst ER, Vogt PH. The AZFa gene DBY (DDX3Y) is widely transcribed but the protein is limited to the male germ cells by translation control. Hum Mol Genet 2004; 13:2333-41

18. Sargent CA, Boucher CA, Kirsch S, Brown G, Weiss B, Trundley A, et al. The critical region of overlap defining the AZFa male infertility interval of proximal Yq contains three transcribed sequences. J Med Genet 1999; 36:670-7

19.Blagosklonova O, Fellmann F, Clavequin MC, Roux C, Bresson JL. AZFa deletions in sertoli cell only syndrome : a retrospective study. Mol Hum Reprod 2000; 6(9) : 795-9

20.Langman J. Langman's medical embryology. Montana: Twin Bridges; 2007. p. 337

21.Grant DB, Laurence BM, Atherden SM, Ryness J. HCG stimulation test in children with abnormal sexual development. Arch Dis Child 1976; 51:596-601

22. Anugerah P, editor. Patofisiologi : konsep klinis proses-proses penyakit. ed. 4. Jakarta : EGC; 1992. p. 1147-9

23.Baldi M, Luetjens MC, Tuettelmann F, Nieschlag E, Simoni M. Leydig cells activity is impaired in patients with Sertoli Cell only Syndrome. Endocrine abstracts 2008; $16: 634$

24.Mak V, Jarvi KA. The genetics of male infertility. J Urology 1996; 156 : 1245-57 